\title{
Students' Personalities and the Level of Engagement in Co-Curricular Activities
}

\author{
Syed Mohd Najib Syed Yahya, Faridah Mydin Kutty, Norfarizah Adira Abd Hadi \\ Faculty of Education, Universiti Kebangsaan Malaysia (UKM), Bangi, Malaysia \\ Email: faridah_mydin@ukm.edu.my
}

How to cite this paper: Yahya, S. M. N. S., Kutty, F. M., \& Hadi, N. A. A. (2019). Students' Personalities and the Level of Engagement in Co-Curricular Activities. Creative Education, 10, 2984-2992. https://doi.org/10.4236/ce.2019.1012222

Received: October 21, 2019

Accepted: November 26, 2019

Published: November 29, 2019

Copyright $\odot 2019$ by author(s) and Scientific Research Publishing Inc. This work is licensed under the Creative Commons Attribution International License (CC BY 4.0).

http://creativecommons.org/licenses/by/4.0/

\begin{abstract}
This study aimed to examine the relationship between students' personalities with their level of engagement in co-curricular activities in schools around the Kuala Lumpur Sentul Zone. This quantitative study used survey questionnaires and involved 351 respondents consisting of selected Form 4 students from four selected schools. Correlation analysis showed that there was a significant relationship $(r=0.762, p=0.00)$ between students' personalities and their engagement in co-curricular activities among students. The results showed that students' personalities can be developed and their level of engagement in co-curricular activities can also be determined.
\end{abstract}

\section{Keywords}

Student Personality, Student Engagement and Co-Curriculum

\section{Introduction}

Recently, new changes in Malaysian education system emerged as the Malaysian Education Development Plan (PPPM) 2013-2025 is gradually being implemented. The plan is designed to reflect the national education philosophy of "...an ongoing effort to further develop the potential of a holistic and integrated individual in creating intellectually, spiritually, emotionally and physically balanced citizen based on trust and obedience to God." The policy by Malaysian's Minister of Education (MOE) also focuses on shaping and developing students' personalities. The curriculum and co-curricular systems are created by the MOE is clear in shaping students' personalities in schools. The personalities are not only shaped through the education system but also with various factors including families, friends, cultural influences, breeds, body shapes, intelligence and emotions (Yahaya et al., 2008). Therefore, factors that influence personality development will produce different characters or personalities since the source of the 
development varies. According to Malek (2005), Halim \& Chieng (2016) and Kwai (2010), the process in building an individual's personality must be continuous and comprehensive without any separation between curriculum and co-curriculum. The development of students' personalities and generic skills in schools varies in many ways and strongly associated with involvement in co-curricular activities (Esa et al., 2004). An example given by Smith \& Comyn (2004) and Blumenthal (2009) shows that students who engaged in co-curricular activities were able to manage time and become more disciplined. This is because co-curriculum education emphasized on the aspect of self-discipline. Therefore, educational psychology needs to be emphasized in schools so that students' daily lives are better managed in line with the national education philosophy.

\section{Problem Statement}

In terms of personality, Mustafa et al. (2014) reported that current students' personalities were at a moderate level. Students have a variety of personalities and require some efforts to acquire superior personalities. However, it is not possible to form a superior personality even if their engagement in co-curricular activities is at a moderate level. In terms of students' engagement in co-curricular activities, Hasan et al. (2013) and Jemaan (2013) stated that students' engagement in co-curricular activities was at moderate level even though it was conducted throughout the year. Muamat (2016) supported the finding by stating that students' engagement in co-curricular activities was inconsistent throughout the year and focused only on programs or competitions. Allen et al. (2015) reported that students who did not engage in any co-curricular activities were affecting their level of personalities. In the light of such situations, the main question that needs to be addressed is whether personality is formed through co-curricular activities in schools and if yes, why the students were still not acquiring the best personalities even though they have been following co-curricular activities for a long time. Next, whether the cause of the current problems that occur is due to 1) how the system was developed, 2) the methods used by school's administration, 3) the students' problematic personalities on their own, 4) the social influences encounter by the students or 5) other possible issues that may influence the students. To overcome the problems, the researchers decided to identify whether the students' personalities were developed through the cocurricular activities and the relationship between the students' personalities and their engagement in co-curricular activities. Therefore, this study focused on the impact between different types of students' personality and their level of engagement in co-curricular activities in school.

\section{Research Objectives}

1) To identify the types of personality among Form 4 students in Secondary Schools around Kuala Lumpur Sentul Zone. 
2) To identify the level of engagement in co-curricular activities among Form 4 students in Secondary Schools around Kuala Lumpur Sentul Zone.

3) To identify the relationship between personality and engagement in co-curricular activities among Form 4 students in Secondary Schools around the Kuala Lumpur Sentul Zone.

\section{Literature Review}

This study was based on the Big Five Personality Theory (Goldberg, 1992). The theory is described as a comprehensive framework to measure one's personality. The theory was developed through a comprehensive dimension known as "OCEAN" namely Open-ness, Conscientiousness, Extraversion, Agreeableness, and Neuroticism. Each of the dimension would be analyzed into high scores or low scores. A person's personality score can be determined based on a scale. For example, if you have a high extraversion score, you are more likely to make friends. Meanwhile if you have a low extraversion scores, you have the tendency to pull away from hanging out with people around (Lounsbury et al., 2003; Iskandar, 2013). The OCEAN model introduces dimensions that are likely related to the changes in personality traits of an individual that could affect one's goals for life and self-concept (McCrae \& Costa, 1994). The dimensions of the "Big Five" and their aspects are intertwined with individuals that could influence the behavior of future generations that could generally affect the balance of life (Jang et al., 2002; Roberts \& Del Vecchio, 2000). According to Noftle \& Robins (2007), the Big Five Personality Theory is the most widely used approach to explain students' behavior in learning and achievement. Meanwhile, in terms of implementation, most activities are carried out throughout the year with schools aiming at developing students with superior personalities. It would be in line with the national educational goal, aiming at producing and shaping balanced and holistic behaviors and personalities in an individual. Implementation of these co-curricular activities can be done in or outside of the classroom as appropriate to the situation. Implementation of co-curricular activities should include prior preparations and past experiences in order to develop interests, physical, spiritual, mental, and other values. According to Ashaari (2007), schools need to carry out co-curricular activities that focus on the development of the individual's potential in terms of improving personality, discipline, well-being and communication skills. Previous study by Hasan et al. (2013), found that students' engagement in co-curricular activities was moderate even though it was conducted throughout the year. He added that the students were also less interested and did not fully commit themselves to participate in the co-curricular activities. Muamat (2016) found that students' involvement in co-curricular activities was inconsistent throughout the year and focused only on programs or competitions. Jemaan (2013) found that students' engagement in co-curricular activities was moderate. This indicates that students' engagement in co-curricular activities is inactive. However, many studies have shown that involvement in 
co-curricular activities has positive effects on students' self-esteem. Hassan \& Safar (2010) stated that engaging in co-curricular activities had a positive effect on the development of students' personalities. Pulford \& Sohal (2006), Richardson et al. (2012) and Haron \& Idris (2010) pointed out that students who engaged in co-curricular activities were able to manage their time, became more disciplined and further shaped a disciplinary personality within the individual. This is crucial as it could directly educate an individual's personality, which will further influence their performance. Thus, it can be concluded that there is a link between students' personalities and their engagement in co-curricular activities.

\section{Methodology}

In this study, the researcher used a quantitative research method by using questionnaire as the instrument to obtain the research data. The research sample involved a total of 351 respondents through random sampling technique. The population was taken among Form 4 students from four selected schools around Kuala Lumpur Sentul Zone. The pilot study used Cronbach's alpha to obtain reliability scores. The mean value of the 30 student personality items was 0.79 . Meanwhile, 33 co-curriculum items showed a Cronbach's alpha value of 0.89 . Both of these values indicate that the reliability of the study is good and appropriate. This is because according to Guilford's Rule of Thumb (Guilford \& Fruchter, 1973), alpha values $>0.9$ are excellent and alpha values $>0.8$ are good. In addition, this study used descriptive statistics instruments to describe the types of personality and the level of engagement in co-curriculum activities by looking at the value of frequency scores, percentages, mean and standard deviation. Meanwhile, the inference statistics used Pearson Correlation analysis to examine the relationship between types of personality and engagement in cocurricular activities among secondary school students around Kuala Lumpur.

\section{Findings and Discussions}

The findings of this study were divided into three sections. The first section was to determine the types of personality among Form 4 students in secondary schools around the Kuala Lumpur Sentul zone. The second section was to determine the level of engagement in co-curricular activities among Form 4 students at the Secondary School Kuala Lumpur Sentul Zone. Finally, the third section was to determine the relationship or correlation between the personality and engagement in co-curricular activities among the Form 4 students at the Secondary School Kuala Lumpur Sentul Zone.

\subsection{Types of Personality}

The analysis results of types of personality among Form 4 students in selected secondary schools in Kuala Lumpur Sentul Zone are shown in Table 1. The results showed that the overall personality of the students was at a moderate to 
Table 1. Mean and standard deviation for types of personality.

\begin{tabular}{ccc}
\hline Type of Personality & Mean & SD \\
\hline Personality Extraversion & 3.645 & 0.704 \\
Personality Agreeableness & 3.590 & 0.687 \\
Personality Conscientiousness & 3.646 & 0.643 \\
Personality Neuroticism & 3.476 & 0.642 \\
Personality Openness & 3.667 & 0.650 \\
Overall Student Personality Mean & 3.605 & 0.513 \\
\hline
\end{tabular}

high level with an overall mean value (Mean $=3.605, \mathrm{SD}=0.513$ ). The finding is in line with the study by Mustafa et al. (2014), who found that students' level of personalities was at moderate level. However, the differences in personalities that exist between students are considered normal because psychodynamic scholars consider differences in personality traits are not permanent and have the tendency to become stable (John \& Srivastava, 1999). The data also detailed the mean and standard deviation scores for the types of personality according to the Big Five Personality model-all of which were at moderate to high levels.

\subsection{Level of Engagement in Co-Curricular Activities}

The analysis results of level of engagement in co-curriculum activities among Form 4 students in selected secondary schools in Kuala Lumpur Sentul Zone are shown in Table 2. In overall, the findings indicated that the student's engagement in co-curricular activities was at a moderate-to-high level with an overall mean value (Mean $=3.710, \mathrm{SD}=0.600$ ). The data indicated that all items were at the highest to moderate level, while the lowest and highest means were each recorded a mean score of $($ Mean $=3.297, \mathrm{SD}=0.980)$ and $($ Mean $=3.954, \mathrm{SD}=$ 0.954). This finding showed that there was a lack of effort in ensuring that all students were fully engaged in co-curricular activities. This is in line with the study of Hasan et al. (2013) and Jemaan (2013), who found that students' engagement in co-curricularactivities was at moderate level even though it was conducted throughout the year.

\subsection{Relationship between Personality and Engagement in Co-Curricular Activities}

The relationship between personalities and involvement in co-curriculum activities among Form 4 students in selected secondary schools in Kuala Lumpur Sentul Zone was tested using Pearson correlation. The results of the correlation test are shown in Table 3. The results showed that there was a significant positive relationship $(r=0.76, p=0.00)$ between personalities and engagement in co-curricular activities among students. This showed that the type of personality plays a role in determining the level of involvement in co-curricular activities among students. Positive engagement resulted with positive impacts in personalities' development. This explained how involvement in co-curriculum activities 
Table 2. Mean and standard deviation for level of engagement in co-curricular activities.

\begin{tabular}{cccc}
\hline No. & \multicolumn{1}{c}{ Item n (351) Engagement } & Mean & SD \\
\hline 1 & I always follow the teacher's instructions during co-curricular activities & 3.851 & 0.943 \\
2 & I use my free time to get involved in club activities and associations & 3.583 & 1.098 \\
3 & $\begin{array}{l}\text { I respect people more than I do because of my involvement in co-curricular } \\
\text { activities }\end{array}$ & 3.954 & 0.954 \\
4 & I carry out the tasks that my leader gives me faithfully and earnestly. & 3.826 & 0.976 \\
5 & $\begin{array}{l}\text { I dare to express myself even though it differs from others' experiences } \\
\text { through organizing experience }\end{array}$ & 3.394 & 0.998 \\
6 & I joined clubs and associations at my choice of teachers. & 3.323 & 1.129 \\
7 & I joined a co-curriculum unit based on the strength of the teachers & 3.297 & 0.980 \\
8 & I love being involved in the co-curriculum committee & 3.486 & 1.222 \\
9 & $\begin{array}{l}\text { I always plan on assignments for co-curricular activities that would be } \\
\text { conducted }\end{array}$ & 3.511 & 1.009 \\
10 & I love the value of leadership in co-curricular activities & 3.523 & 1.045 \\
\hline & Total min total & 3.710 & 0.600 \\
\hline
\end{tabular}

Table 3. Relationship between personality and engagement in co-curricular activities.

\begin{tabular}{cccc}
\hline & & $\begin{array}{c}\text { Mean of Overall } \\
\text { Personality Curriculum } \\
\text { Engagement }\end{array}$ & $\begin{array}{c}\text { Mean of Overall } \\
\text { Personality Curriculum } \\
\text { Engagement }\end{array}$ \\
\hline Mean of Overall & Pearson Correlation & 1 & $0.762^{* *}$ \\
Personality & Sig. (2-tailed) & & 0.000 \\
Mean of Curriculum & Pearson Correlation & $0.762^{* *}$ & 351 \\
Engagement & Sig. (2-tailed) & 0.000 & 1 \\
& $\mathrm{~N}$ & 351 & 351 \\
\hline
\end{tabular}

could shape students' personalities. The results can be supported by Hassan \& Safar (2010), Harun \& Salamuddin (2010) and Bar-On (2000) that personalities can be constructed with engagement in co-curricular activities as students' performances and personalities are related and influenced by one another. Laborde et al. (2015) stated that the construction of personal personality can be enhanced through students' involvement in co-curricular activities. Allen et al. (2015) added that physical activity in co-curriculum activities could lead to positive changes for students while at the same time helpful in changing the stability of a student's personality.

\section{Implications}

This study found that differences in personality traits are due to two main factors-geneticfactor and environmental factor. The genetic factor is derived from the offspring of the paternal family from the paternal side. According to Yahaya \& Ahmad (2010), the genetic factor influences more on the development of body shape or physical condition but not on the development behavior itself. Devel- 
opment of behavior is influenced by environmental factor such as family, friends, school, and community. For example, families with positive values will influence their children with positive personality development. Therefore, the development of students' personalities should be emphasized through these two key factors in order to produce a holistic and balanced generation in the future. This study also found that there was a lack of resources to ensure that all students are fully engaged in co-curricular activities. The moderate level of engagement was due to students being less interested and not fully committed to participate in co-curricular activities. This is supported by Muamat (2016), Che-Ani (2017) and Annamalai (2012), stating that students are less interested to engage in co-curricular activities in addition to their inconsistent engagement throughout the year. This issue is needed to be addressed seriously as such condition could affect the development of students' personalities. This study also discovered that the level of engagement in co-curricular activities plays a role in determining students' personalities. There was a strong link between personality and engagement in co-curricular activities as it could shape one's personality. Akhir et al. (2017) reported that engaging in a co-curricular activity is one of the mediums to develop personality domains such as social, effective and psychomotor. Students could also develop leadership and professionalism traits (Hassan \& Safar, 2010; Shahiri \& Adnan, 2015; Amin et al. 2017; Ghozali \& Kamri, 2017). The combination of these aspects could lead to the success of an organization, school or local community.

\section{Conclusion}

Based on the explanations presented in this study, it can be concluded that students need to develop their personalities by engaging in co-curricular activities. It is important for schools, District Education Office, State Education Office and Ministry of Education Malaysia (MOE) to conduct in-depth researches on cocurricular activities embedded with the aspects of personality development in schools. In conclusion, engagement in co-curricular activities could influence the development of students' personalities and it is important to take immediate action to ensure engagement is consistent at a higher rate and impactful in developing students' personalities.

\section{Funding}

This research is supported by Universiti Kebangsaan Malaysia under research "Dana Penyelidikan FPend" scheme No. PP-FPEND-2019.

\section{Conflicts of Interest}

The authors declare no conflicts of interest regarding the publication of this paper.

\section{References}

Akhir, M. A. M., Wahab, M. N. A., \& Ali, Z. M. (2017). Pengukuran dan Penilaian Tahap 
Emosi Pelajar dalam Aktiviti Kokurikulum: Permasalahan dan Cadangan. International Journal of Humanities Technology and Civilization, 1, 2.

Allen, M. S., Vella, S. A., \& Laborde, S. (2015). Health-Related Behaviour and Personality Trait Development in Adulthood. Journal of Research in Personality, 59, 104-110. https://doi.org/10.1016/j.jrp.2015.10.005

Amin, A. F. M., Amir, R., Rahman, S., \& Lubis, M. A. (2017). Profile of Self-Identity amongst Adolescents: A Study in Johor. ASEAN Comparative Education Research Journal on Islam and Civilization, 1, 124-134.

Annamalai, M. (2012). Pengaruh penglibatan dalam kokurikulum sekolah terhadap kemahiran insaniah: Peranan sokongan keluarga dan pengaruh rakan sebaya. Doctoral Dissertation, Penang: Universiti Sains Malaysia.

Ashaari, O. (2007). Pengurusan Sekolah: Satu Panduan Lengkap. Kuala Lumpur: Utusan Publication \& Distribution Sdn. Bhd.

Bar-On, R. (2000). Emotional and Social Intelligence: Insights from the Emotional.

Blumenthal, K. J. (2009). Collegiate Recreational Sports: Pivotal Players in Student Success. Planning for Higher Education, 37, 52.

Esa, A., Mohd Yunus, J., \& Kaprawi, N. (2004). The Implementation of Generic Skill through Co-Curriculum Activity in Polytechnic to Fulfill the Industrial Demand: Proposal Paper.

Ghozali, M., \& Kamri, N. A. (2017). Keperibadian Islam dan profesionalisme dalam pekerjaan: Satu analisis teoritis. Jurnal Syariah, 23, 255-286.

Goldberg, L. R. (1992). The Development of Markers for the Big-Five Factor Structure. Psychological Assessment, 4, 26. https://doi.org/10.1037/1040-3590.4.1.26

Guilford, J., \& Fruchter, B. (1973). Instructor's Manual to Accompany Fundamental Statistics in Psychology and Education. New York: McGraw-Hill.

Guilford, J., \& Fruchter, B. (1973). Instructor's Manual to Accompany Fundamental Statistics in Psychology and Education. New York: McGraw-Hill.

Halim, F., \& Chieng, L. S. (2016). The Relationship of Self Determination and Big Five Personality to Achievement Motivation and Academic Achievement. Jurnal Psikologi Malaysia, 30, 2.

Haron, Z., \& Idris, A. A. (2010). Persepsi Pelajar Terhadap Penerapan Kemahiran Generik Dalam Aktiviti Kokurikulum Di Kalangan Pelajar Tahun Dua Fakulti Pendidikan, Universiti Teknologi Malaysia, Skudai. Universiti Teknologi Malaysia.

Harun, M. T., \& Salamuddin, N. (2010). Cultivating Personality Development through Outdoor Education Programme: The Malaysia Experience. Procedia-Social and Behavioral Sciences, 9, 228-234. https://doi.org/10.1016/j.sbspro.2010.12.141

Hasan, M. F., Kadir, S. A., \& Asimiran, S. (2013). Relationship School Environment with Students Involvement in Co-Curricular Activities in Secondary Schools. Malaysian Journal of Education, 38, 1-9.

Hassan, J., \& Safar, S. A. (2010). Pembinaan Kecemerlangan Diri Pimpinan Pelajar Menerusi Penglibatan Dalam Aktiviti Kokurikulum Di Universiti Teknologi Malaysia, Skudai. http://eprints.utm.my/id/eprint/10788/

Iskandar, L. M. (2013). Penyesalan pasca pembelian ditinjau dari big five personality. Jurnal Psikologi, 40, 81-91.

Jang, K. L., Livesley, W. J., \& Vernon, P. A. (2002). The Etiology of Personality Function: The University of British Columbia Twin Project. Twin Research and Human Genetics, 5, 342-346. https://doi.org/10.1375/136905202320906066 
Jemaan, M. (2013). Penglibatan pelajar sekolah menengah kawasan parlimen Bakri Muar dalam aktiviti kokurikulum dan hubungannya dengan kecerdasan emosi. Doctoral Dissertation, Skudai: Universiti Teknologi Malaysia.

John, O. P., \& Srivastava, S. (1999). The Big Five Trait Taxonomy: History, Measurement, and Theoretical Perspectives. In L. A. Pervin, \& O. P. John (Eds.), Handbook of Personality: Theory and Research (Vol. 2, pp. 102-138). New York: Guilford Press.

Kwai, T. Y. (2010). Pengurusan Kokurikulum. Kuala Lumpur: Kumpulan Budiman Sdn. Bhd.

Laborde, S., Guillen, F., Dosseville, F., \& Allen, M. S. (2015). Chronotype, Sport Participation, and Positive Personality-Trait-Like Individual Differences. Chronobiology International, 32, 942-951.

Lounsbury, J. W., Sundstrom, E., Loveland, J. M., \& Gibson, L. W. (2003). Intelligence, "Big Five" Personality Traits, and Work Drive as Predictors of Course Grade. Personality and Individual Differences, 35, 1231-1239. https://doi.org/10.1016/S0191-8869(02)00330-6

Malek, A. H. A. (2005). Faktor-faktor penghalang dalam pengurusan kokurikulum di sebuah sekolah menengah di Melaka. Doctoral Dissertation, Institut Pengajian Kepengetuaan, Universiti Malaya.

McCrae, R. R., \& Costa Jr., P. T. (1994). The Stability of Personality: Observations and Evaluations. Current Directions in Psychological Science, 3, 173-175. https://doi.org/10.1111/1467-8721.ep10770693

Muamat, O. (2016). Persepsi pelajar terhadap amalan pengajaran guru opsyen dan bukan opsyen sejarah serta hubungannya dengan sikap pelajar. Masters. Universiti Kebangsaan Malaysia.

Mustafa, M., Jusoh, A., Syed Salim, S., Bistaman, M., \& Mohamed Arip, M. (2014). Personaliti Pelajar Program Pendidikan. Jurnal Pendidikan Bitara UPSI, 7, 68-76.

Noftle, E. E., \& Robins, R. W. (2007). Personality Predictors of Academic Outcomes: Big Five Correlates of GPA and SAT Scores. Journal of Personality and Social Psychology, 93, 116. https://doi.org/10.1037/0022-3514.93.1.116

Pulford, B. D., \& Sohal, H. (2006). The Influence of Personality on HE Students' Confidence in Their Academic Abilities. Personality and Individual Differences, 41, 14091419. https://doi.org/10.1016/j.paid.2006.05.010

Richardson, M., Abraham, C., \& Bond, R. (2012). Psychological Correlates of University Students' Academic Performance: A Systematic Review and Meta-Analysis. Psychological Bulletin, 138, 353. https://doi.org/10.1037/a0026838

Roberts, B. W., \& DelVecchio, W. F. (2000). The Rank-Order Consistency of Personality Traits from Childhood to Old Age: A Quantitative Review of Longitudinal Studies. Psychological Bulletin, 126, 3. https://doi.org/10.1037/0033-2909.126.1.3

Shahiri, H., \& Adnan, S. N. (2015). The Relevancy of Co-Curricular Activities on Graduates Employability: Evidence from a Graduate Unemployment Duration Model.

Smith, E., \& Comyn, P. (2004). The Development of Employability Skills in Novice Workers through Employment. In Generic Skills in Vocational Education and Training: Research Readings (pp. 95-108). Leabrook: ERIC Clearinghouse.

Yahaya, A., \& Ahmad, N. (2010). Teori-Teori Konsep Kendiri. http://eprints.utm.my/id/eprint/10368/

Yahaya, A., Boon, Y., Hashim, S., Mustafa, M. S., \& Muhammad, Z. (2008). Indeks perlakuan buli di kalangan pelajar-pelajar di sekolah menengah dan rendah di Malaysia. Research Report, Johor: Malaysia University of Technology. 